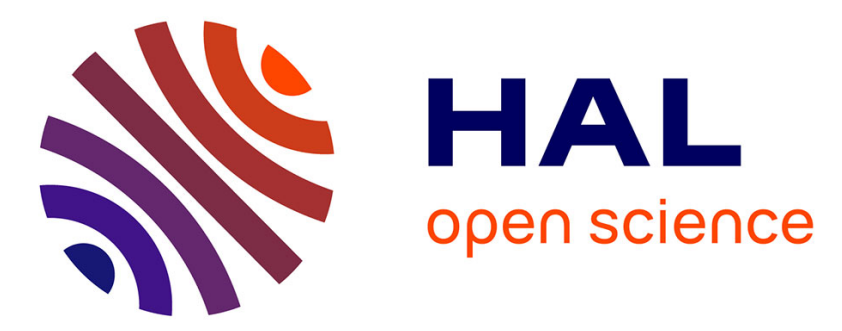

\title{
A method for assessing available phosphorus content in arable topsoils over large spatial scales
}

Stéphane Follain, Christian Schvartz, Pascal Denoroy, Christine Villette, Nicolas P.A. Saby, Dominique Arrouays, Blandine Lemercier, Christian Walter

\section{- To cite this version:}

Stéphane Follain, Christian Schvartz, Pascal Denoroy, Christine Villette, Nicolas P.A. Saby, et al.. A method for assessing available phosphorus content in arable topsoils over large spatial scales. Agronomy for Sustainable Development, 2009, 29 (2), pp.371-379. 10.1051/agro:2008046 . hal-00886412

\section{HAL Id: hal-00886412 \\ https://hal.science/hal-00886412}

Submitted on 1 Jan 2009

HAL is a multi-disciplinary open access archive for the deposit and dissemination of scientific research documents, whether they are published or not. The documents may come from teaching and research institutions in France or abroad, or from public or private research centers.
L'archive ouverte pluridisciplinaire HAL, est destinée au dépôt et à la diffusion de documents scientifiques de niveau recherche, publiés ou non, émanant des établissements d'enseignement et de recherche français ou étrangers, des laboratoires publics ou privés. 


\title{
A method for assessing available phosphorus content in arable topsoils over large spatial scales
}

\author{
Stéphane Follain ${ }^{1,6 *}$, Christian Schvartz ${ }^{1}$, Pascal Denoroy ${ }^{2}$, Christine VilleTte $^{3}$, Nicolas P.A. SABY ${ }^{4}$, \\ Dominique ARrouAYs ${ }^{4}$, Blandine LEMERCIER ${ }^{5}$, Christian WALTER $^{5}$ \\ ${ }^{1}$ ISA, Laboratoire Sols et Environnement, 48 boulevard Vauban, 59046 Lille, France \\ ${ }^{2}$ UMR INRA / ENITA Bordeaux, TCEM (1220), INRA Centre de Recherche de Bordeaux-Aquitaine, 71 avenue Edouard Bourlaux, BP 81, \\ 33883 Villenave d'Ornon Cedex, France \\ ${ }^{3}$ Laboratoire Départemental d'Analyses et de Recherche, rue Fernand Christ, 02007 Laon Cedex, France \\ ${ }^{4}$ INRA, US 1106, CR d'Orléans, Unité Infosol, avenue de la Pomme de Pin, BP 20619 Ardon, 45166 Olivet Cedex, France \\ ${ }^{5}$ UMR INRA / Agrocampus Rennes Sol, Agronomie et Spatialisation, 65 rue de Saint-Brieuc, CS 84215, 35042 Rennes, France \\ ${ }^{6}$ UMR LISAH / Montpellier SupAgro / INRA / IRD, 2 place Pierre Viala, 34060 Montpellier Cedex 2, France
}

(Accepted 9 July 2008)

\begin{abstract}
Human activities, and more specifically agricultural activities, have modified the way the ecosystem functions through the use of fertilizers. When these inputs are not being utilized reasonably, they can lead to a degradation in both soil and water quality. As a result of the subsequent environmental problems and socio-economic constraints, the concept of sustainable fertilization was born. The main goal behind sustainable fertilization is to reduce the amount of fertilizers used while maintaining soil fertility and farmer revenues. We have designed herein a methodology for assessing the phosphorus bioavailability in arable topsoils on France's national scale, on the basis of this sustainable fertilization concept. We will consider the sustainability of a cropping system that requires balancing nutrient removal from the soil by fertilization, in order to avoid environmental risks. The originality of this method lies in quantitative results stemming from the French Soil Test Database (BDAT) and their evaluation using the RegiFert ${ }^{\circledR}$ software, which incorporates soil characteristics and crop sensitivity to nutrient availability. According to the proposed procedure, we determined the phosphorus bioavailability class of French arable soils at the cantonal scale. Cantons are areas of average surface of $140 \mathrm{~km}^{2}$. This methodology constitutes an attempt to gather all analytical results into a common diagnostic framework on the national scale (for France), while taking into account the local pedological context and crop production requirements. With this procedure, we are able to conclude that $77 \%$ of cantons are situated below the critical level regarding crop needs. Furthermore, this diagnosis suggests that the available phosphorus content in soils is considered insufficient with respect to any crop potential requirement. From an environmental standpoint, however, this situation could be considered as generating the lowest pollution risk. Nevertheless, 23\% of the cantons exhibit a soil phosphorus accumulation that is not necessary with regard to agricultural uses. In this case, no fertilization is required and the pollution risk is increased. On the national scale, bioavailability class frequencies are structured spatially, with gradients correlated to soil parameter spatial distribution, and tend to reflect land use patterns.
\end{abstract}

soil fertility / sustainable agriculture / sustainable fertilization / available phosphorus / soil database / BDAT

\section{INTRODUCTION}

Since the Second World War, human activities, and more specifically agricultural activities, have modified ecosystem operations through the extensive use of inputs. This is particularly true for fertilizers of both the mineral and organic varieties. When these inputs are not being spread in reasonable quantities, they may lead to a degradation in both soil and water quality. An example for phosphorus has been presented by Withers et al. (2001), who reported that the productive grassland and arable areas in the UK had accumulated an average

* Corresponding author: follain@ supagro.inra.fr
$\mathrm{P}$ surplus of $1000 \mathrm{~kg} \mathrm{ha}^{-1}$ over the last 65 years. This excess in $\mathrm{P}$ inputs may cause environmental problems, such as phosphorus transfer to freshwater systems, that leads to eutrophication (Edwards and Withers, 1998; Sharpley et al., 2000). A sustainable management of fertilization use should be able to permanently adapt fertilizer inputs to variable yield objectives, in both quantity and quality terms, in order to minimize pollution risks (Thévenet, 1993; COMIFER, 1993). As part of this concept, the agronomic assessment of soil $\mathrm{P}$ content, along with related recommendations in terms of required fertilizer amounts, are based on soil nutrient bioavailability classes. These classes (Fig. 1) are determined by taking into account: (i) the soil type and characteristics known through 


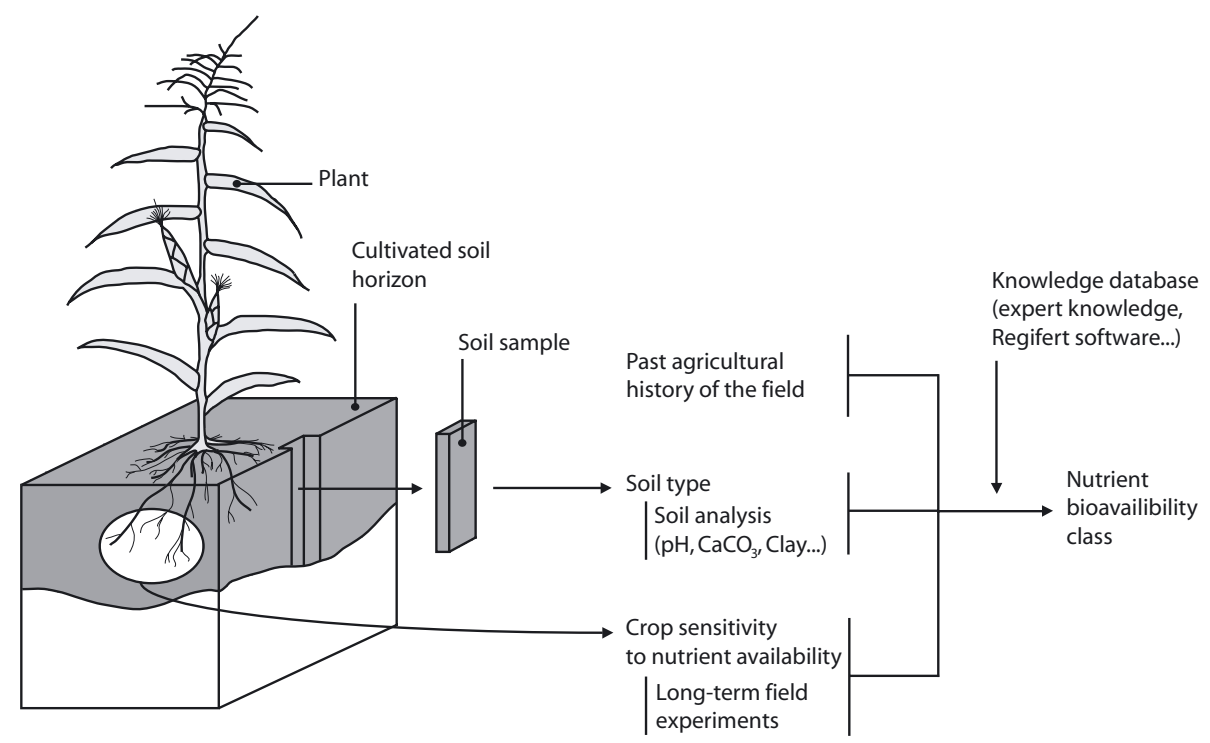

Figure 1. The "sustainable fertilization" concept: determination of soil bioavailability class.

soil analyses and morphological descriptions; (ii) the crop sensitivity to nutrient availability, as assessed by the results of long-term field experiments (Morel et al., 1984; Gachon, 1988; ITCF, 1988; COMIFER, 1993); and (iii) previous agricultural history from the field. On the basis of these data and through use of a knowledge database, a nutrient bioavailability status can be determined. The objective here is to avoid excess fertilization, which has been occurring all too often in the past (Pellerin et al., 2000).

In this article, we will use the definition of soil fertility put forward by Stockdale et al. (2002), i.e.: "the capacity of a soil to supply nutrients to crops". In this manner, "the sustainability of cropping systems requires that nutrient removal from the soil be balanced by nutrient replacement, to avoid excess nutrient accumulation or depletion of nutrient reserves in soils" (Wivstad et al., 2005). This concept can be called "sustainable fertilization" and is considered a part of sustainable agriculture.

Sustainability of the farming system must be monitored over long periods, due to the strong interaction taking place between soil and most nutrient minerals, thereby inducing long-term effects from fertilizers on crop yields (Cope, 1981; Aulakh et al., 1991); Kamprath (1967) reported that corn yields were affected for the seven to nine years subsequent to large P load applications. It is therefore necessary to develop monitoring systems for surveying the spatial and temporal changes in soil properties on the local or national scales (Skinner and Todd, 1998; Lettens et al., 2004; Zhang et al., 2004). In pursuit of such an objective, the French Soil Test Database (BDAT) (Walter et al., 1997; Schvartz et al., 1997; Saby et al., 2004; Lemercier et al., 2006, 2008) has been created to monitor, within a single database, results from soil analyses commissioned by farmers to adapt fertilization inputs on the field scale.

In France, the initial agronomic experiment with an automated interpretation of soil analyses for guidance purposes began with a scientific program directed by the French Institute for Agronomic Research (INRA) in the 1970s. The ensuing procedure was based on the standards suggested by Rémy and Marin-Laflèche (1974). The resulting proposed standards were based on agronomic interpretation and depended strictly on the associated soil parameters, i.e.: clay fraction and soil organic matter content. These standards were subsequently used by Walter et al. (1997) to interpret soil fertility levels of arable topsoils in France over the period 1990-1994. Yet the widespread use of these standards, which were designed for conditions applicable to northern France, could lead to possible inaccuracies in interpretation within the country's other pedoclimatic contexts.

The aim of this study is to propose a methodology for assessing the phosphorus bioavailability class of France's arable topsoil, based on the concept of sustainable fertilization, which incorporates actual field conditions better and uses the most recent parameters obtained from long-term field experiments (Denoroy et al., 2004).

\section{MATERIALS AND METHODS}

\subsection{The RegiFert ${ }^{\circledR}$ software}

The RegiFert ${ }^{\circledR}$ software was initially developed by the French Institute for Agronomic Research (INRA) in collaboration with the Agricultural Research Laboratory of Aisne (LDAR). Its aim is to prescribe crop fertilization guidelines (P, K, Mg...) on the field scale, based on data input from soil analyses (Denoroy et al., 2004). The decision to use this software in the present study is justified by the three following criteria:

- the conceptual framework used by RegiFert ${ }^{\circledR}$ relies upon knowledge from soil analyses and integrates the concept 
Table I. Default threshold values of extractable phosphorus in soil $\left(\mathrm{L}_{1}\right.$ and $\left.\mathrm{L}_{2}, \mathrm{~L}_{1}<\mathrm{L}_{2}\right)$ used by the RegiFert ${ }^{\circledR}$ software to determine soil phosphorus bioavailability class, depending on both the $\mathrm{P}_{2} \mathrm{O}_{5}$ analytical method (Olsen, Joret-Hébert, Dyer) and soil characteristics: CaCO 3 , $\mathrm{pH}$, clay fraction and soil organic carbon (SOC) (Denoroy et al., 2001).

\begin{tabular}{|c|c|c|c|c|c|c|}
\hline \multirow{2}{*}{$\begin{array}{c}\mathrm{P}_{2} \mathrm{O}_{5} \\
\text { method }\end{array}$} & \multirow{2}{*}{$\begin{array}{c}\mathrm{CaCO}_{3} \\
\left(\mathrm{~g} \mathrm{~kg}^{-1}\right)\end{array}$} & \multirow[t]{2}{*}{$\mathrm{pH}$} & \multirow{2}{*}{$\begin{array}{c}\text { Clay } \\
\left(\mathrm{g} \mathrm{kg}^{-1}\right)\end{array}$} & \multirow{2}{*}{$\begin{array}{c}\mathrm{SOC} \\
\left(\mathrm{g} \mathrm{kg}^{-1}\right)\end{array}$} & \multicolumn{2}{|c|}{ Threshold values $\left(\mathrm{mg} \mathrm{kg}^{-1}\right)$} \\
\hline & & & & & $\mathrm{L}_{1}$ & $\mathrm{~L}_{2}$ \\
\hline \multirow{4}{*}{$\begin{array}{c}\text { Olsen } \\
\text { (ISO 11263) }\end{array}$} & \multirow{2}{*}{$30<<800$} & \multirow{2}{*}{$7<<8.3$} & $150<<800$ & \multirow{4}{*}{$>5$} & 50 & 100 \\
\hline & & & \multirow{2}{*}{$10<<150$} & & 45 & 90 \\
\hline & \multirow{2}{*}{$<30$} & \multirow{2}{*}{$5<<8.3$} & & & 40 & 70 \\
\hline & & & $150<<800$ & & 40 & 80 \\
\hline \multirow{4}{*}{$\begin{array}{c}\text { Joret-Hébert } \\
\text { (NFX 31-161) }\end{array}$} & \multirow{2}{*}{$30<<800$} & \multirow{2}{*}{$7<<8.3$} & $150<<800$ & \multirow{4}{*}{$>5$} & 150 & 300 \\
\hline & & & \multirow{2}{*}{$10<<150$} & & 140 & 270 \\
\hline & \multirow{2}{*}{$<30$} & \multirow{2}{*}{$5<<8.3$} & & & 130 & 250 \\
\hline & & & $150<<800$ & & 150 & 260 \\
\hline \multirow{2}{*}{$\begin{array}{c}\text { Dyer } \\
(\text { NFX 31-10) }\end{array}$} & \multirow{2}{*}{$<30$} & \multirow{2}{*}{$4<<9$} & $0<<250$ & \multirow{2}{*}{$>5$} & 150 & 300 \\
\hline & & & $>250$ & & 180 & 400 \\
\hline
\end{tabular}

of sustainable fertilization (COMIFER, 1993; Thévenet, 1993; Schvartz et al., 2005);

- RegiFert ${ }^{\circledR}$ offers the possibility to parameterize the diagnosis by using regional references (soil type, climate, etc.). In this study, we will be using parameter default values; and

- the software can run automated diagnoses on large information flows.

\subsubsection{The phosphorus diagnosis}

RegiFert $^{\circledR}$ provides a crop fertilization prescription based on a two-step procedure: (i) an agronomic assessment of the soil bioavailability level for the considered element $\left(\mathrm{P}_{2} \mathrm{O}_{5}\right.$ in this study); followed by (ii) a recommendation on the quantity of fertilizer to be applied on the field scale in order to maintain fertility levels, in relation to future crop needs for a predetermined yield level. We will use this tool on the national scale and proceed with just the first step of the procedure (i.e. agronomic assessment).

RegiFert $^{\circledR}$ introduces two threshold values $\left(\mathrm{L}_{1}\right.$ and $\mathrm{L}_{2}$, with $\mathrm{L}_{1}<\mathrm{L}_{2}$ ) to interpret the phosphorus content in soils; these values have been defined in Denoroy et al. (2004) as:

- $\mathrm{L}_{1}$ : the quantity of extractable phosphorus that allows reaching at least $95 \%$ of potential crop yield, with a probability of 0.9 and without any complementary fertilization, for plants with low sensitivity to phosphorus availability (e.g. sunflower: Helianthus annus, grain-maize: Zea mays L., wheat: Triticum aestivum);

- $\mathrm{L}_{2}$ : the quantity of extractable phosphorus that allows reaching at least $95 \%$ of potential crop yield, with a probability of 0.9 and without any complementary fertilization, for plants with high sensitivity to phosphorus availability (e.g. beet: Beta vulgaris, potato: Solanum tuberosum).
These threshold values (Tab. I) depend on the analytical methods chosen for $\mathrm{P}_{2} \mathrm{O}_{5}$ as well as on soil characteristics: $\mathrm{CaCO}_{3}$, $\mathrm{pH}$, clay fraction and soil organic carbon (SOC). The diagnostic assessment is performed by comparing soil phosphorus content with the appropriate $\mathrm{L}_{1}$ and $\mathrm{L}_{2}$ threshold values. As a consequence, three classes of bioavailability are defined:

- class $1\left(C_{1}\right)$ : low level, the extractable phosphorus content is less than the $\mathrm{L}_{1}$ threshold value;

- class $2\left(C_{2}\right)$ : intermediate level, the extractable phosphorus content is bounded between the $\mathrm{L}_{1}$ and $\mathrm{L}_{2}$ values;

- class $3\left(C_{3}\right)$ : high level, the extractable phosphorus content is greater than the $\mathrm{L}_{2}$ threshold value.

\subsection{The French Soil Test Database (BDAT)}

This database stores the results from soil analyses commissioned by farmers to calculate fertilization on the field scale. Input data are provided by 34 soil testing laboratories certified by the French Ministry of Agriculture, all of which apply the same analytical standards. The procedure used to create the national database from these initial soil analysis data has been described by Saby et al. (2004). The sampling strategy was unsupervised, which may have introduced a bias now difficult to estimate (Schvartz et al., 1997): only cultivated land is represented in the the database; and both the farmers' technical motivation for choosing the sampled parcels and the analysis frequency remain unknown.

The first application of this database was to study the spacetime variability of the plowed layer nutrient status on the national scale. Data stored in BDAT over the 1990-2004 period were originally geographically located on a municipal scale, but then aggregated on the "cantonal" scale for statistical and 


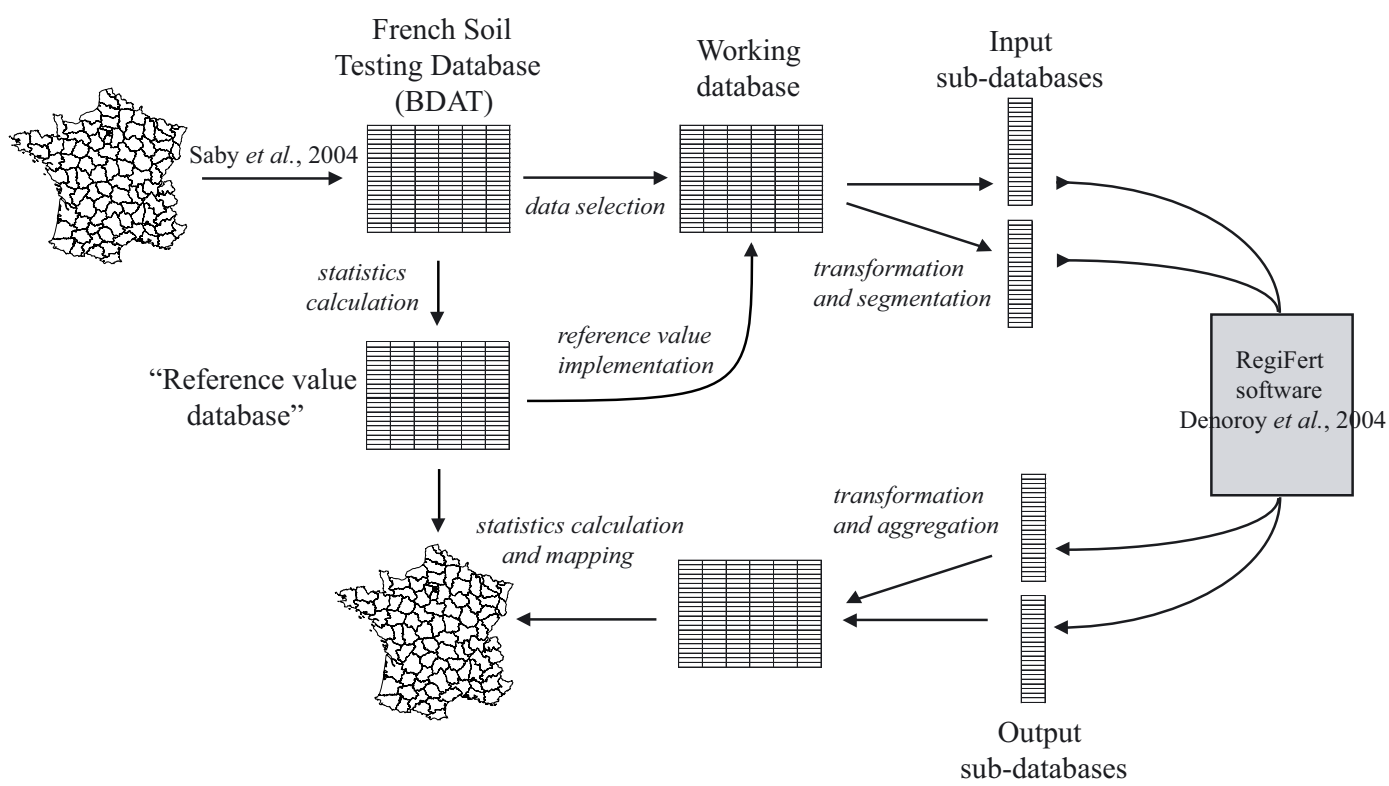

Figure 2. The data processing flowchart. The procedure allows the extraction of useful data (i.e. soil available phosphorus and reference values) from the soil analysis values stored in the French Soil Test Database (BDAT), a diagnosis by the Regifert ${ }^{\circledR}$ software on soil available phosphorus content, and output processing in order to map the phosphorus bioavailability class for large spatial scales.

legal reasons. The French "cantons" are administrative jurisdictions, defined as a grouping of several municipalities with a mean land area of $140 \mathrm{~km}^{2}$.

\subsubsection{Soil phosphorus data}

In the database, a total of 850,606 results from soil analyses contain available phosphorus content values (in $\mathrm{mg} \mathrm{P}_{2} \mathrm{O}_{5} \mathrm{~kg}^{-1}$ ). These values are determined by one of the three standardized methods (AFNOR, 1996) used by French soil analysis laboratories, i.e.:

- the "Dyer" method (NFX 31-10): determination of soluble phosphorus in a citric acid monohydrate solution. This method only applies to soils with less than $2 \%$ carbonates;

- the "Joret-Hébert" method (NFX 31-161): determination of soluble phosphorus in an ammonium oxalate solution. This method applies to all soil types, although acidic conditions may cause overestimation of results; for this reason, the method is generally not used on acid soils;

- the "Olsen" method (ISO 11263): determination of phosphorus in a sodium hydrogen carbonate solution. This method applies under all soil conditions.

\subsubsection{Ancillary data}

Ancillary data are the soil characteristic parameters used by RegiFert ${ }^{\circledR}$ to assess the bioavailability class of soil phosphorus content with respect to soil type and crop production. These parameters are expressed in Table I: soil organic carbon content $\left(\mathrm{g} \mathrm{kg}^{-1}\right)$ (ISO 10694:1995), pH (ISO 10390) of a soil suspension in water, clay fraction $\left(\mathrm{g} \mathrm{kg}^{-1}\right)(\mathrm{X} 31-107)$ and total $\mathrm{CaCO}_{3}$ content $\left(\mathrm{g} \mathrm{kg}^{-1}\right)$ (ISO 10693). This complete set of data is available for only $20 \%$ of the results stored in the BDAT database.

\subsubsection{Reference values}

For $80 \%$ of the soil analyses available in the database, at least one of the ancillary data elements is missing, thus making it impossible to establish a fertility diagnosis for these samples. To overcome this lack of information and in order to integrate these analyses into the procedure, the missing values were replaced by "reference values": for each canton, we calculated reference values using the median of local results, only if more than 9 values were available over the 15 -year study period (1990-2004).

\subsection{Data processing}

\subsubsection{Quantitative assessment of soil phosphorus contents}

Available phosphorus content results were aggregated at the cantonal spatial unit for the entire 15-year duration. For each canton, the phosphorus median content value was calculated separately for each analytical method.

\subsubsection{Qualitative assessment of soil phosphorus fertility}

Figure 2 provides a description of data processing from the initial database to final mapping. For each canton, we define 

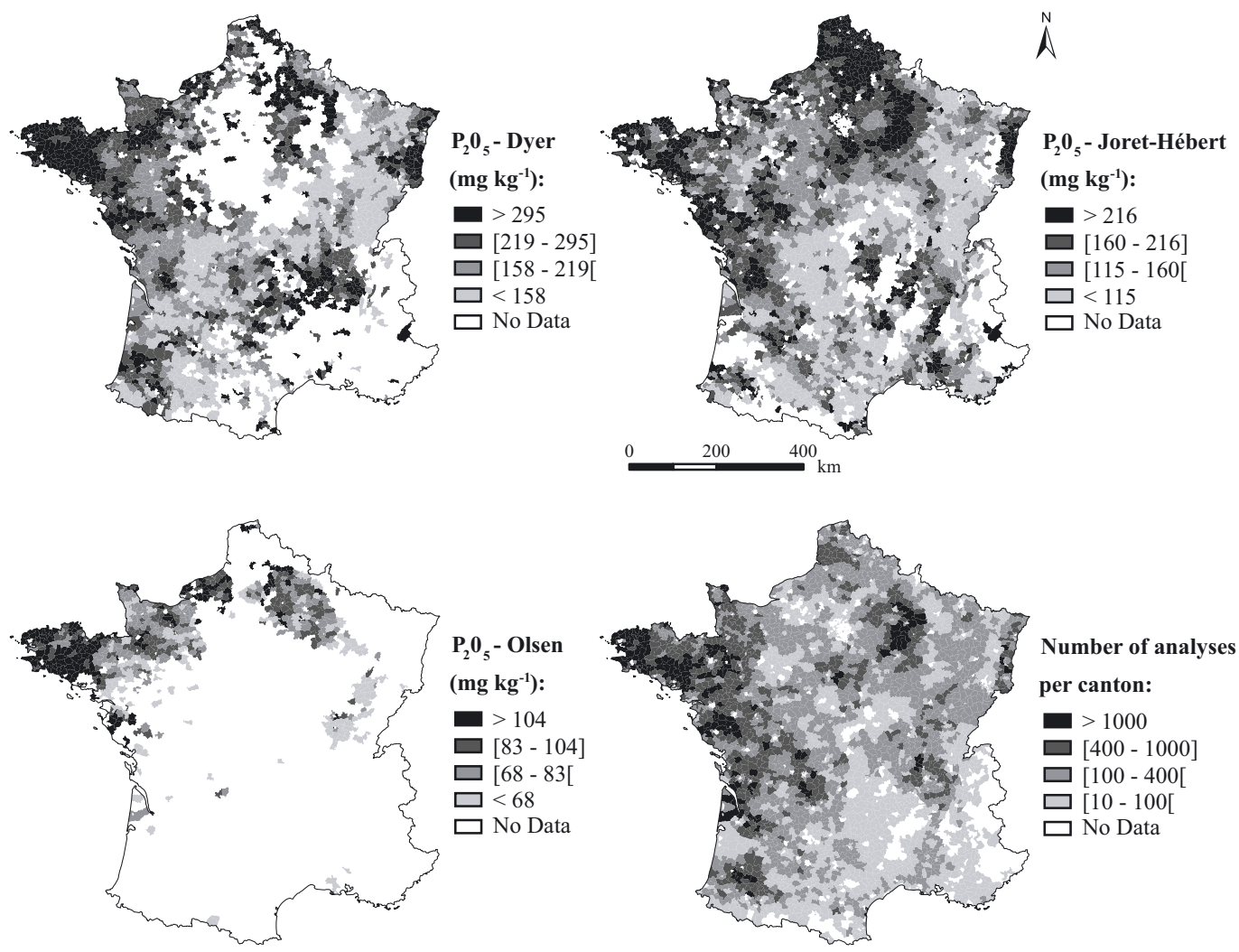

Figure 3. Representation of phosphorus median values, calculated on the cantonal scale, for cases when more than 9 results are available over the 15-year study period. (Class thresholds were determined according to non-parametric statistics: 1st quartile - median - 3rd quartile, as calculated on median values for the entire canton.)

$n C_{X}$ as the number of soil analyses categorized into one of the bioavailability classes $\left(C_{1}, C_{2}\right.$ and $\left.C_{3}\right)$, derived by summing the diagnostic assessments $C_{X}$ obtained for each analytical method (Joret-Hébert, Dyer and Olsen) (Eq. (1)):

$$
n C_{X}=n C_{X, J H}+n C_{X, \text { Dyer }}+n C_{X, \text { Olsen }} .
$$

The frequency $F C_{x}\left(F C_{1}, F C_{2}\right.$ and $\left.F C_{3}\right)$ is calculated as the number of soil analysis results categorized into one of the bioavailability classes, within a given canton $\left(n C_{X}\right)$, divided by the total number of analyses for which the assessment was feasible within the same cantonal unit (Eq. (2)):

$$
F C_{X}=\frac{n C_{X}}{n C_{1}+n C_{2}+n C_{3}} .
$$

\section{RESULTS AND DISCUSSION}

\subsection{Quantitative assessment of soil phosphorus fertility}

By employing the data processing procedure outlined in Figure 2, we built a national cartography of cantonal median soil extractable phosphorus values on the cantonal scale. Figure 3 displays maps of these values, categorized according to the relevant $\mathrm{P}_{2} \mathrm{O}_{5}$ analytical method. On the national scale, we observe a heterogeneous application and spatial distribution of the analytical methods. The greatest national coverage has been produced by the "JoretHébert" method, which accounts for $47 \%$ of all soil analyses. The "Dyer" method represents $43 \%$ of the total soil sample and appears to be distributed heterogeneously on the national scale, yet offers no results for either the Paris Basin or the south of France. The third map, dedicated to the "Olsen" method, shows the least coverage, with just $10 \%$ of the total soil sample and a geographic concentration in the northwestern (Normandy and Brittany) and northeastern (Champagne-Ardennes region) parts of the country.

The highest $\mathrm{P}_{2} \mathrm{O}_{5}$ values ( $>$ 3rd quartile) are observed in western France, especially along the Atlantic cost, northern France and Alsace (eastern France), whereas the smallest values ( $<1$ st quartile) are located in the country's southern and eastern regions.

We calculated "reference values" for $\mathrm{pH}$, organic carbon $\left(\mathrm{g} \mathrm{kg}^{-1}\right), \mathrm{CaCO}_{3}$ content $\left(\mathrm{g} \mathrm{kg}^{-1}\right)$ and clay fraction $\left(\mathrm{g} \mathrm{kg}^{-1}\right)$ on the cantonal scale as the median value for the canton whenever more than 9 analysis results were available over the 15 -year study period (Fig. 4). The $\mathrm{pH}$ reference values are distributed around a median of 7.0 with lower and upper quartiles of 6.2 and 7.8, respectively. The $\mathrm{CaCO}_{3}$ reference values display a median of $1.0 \mathrm{~g} \mathrm{~kg}^{-1}$ and are associated with quartile values of 0.0 and $21.0 \mathrm{~g} \mathrm{~kg}^{-1}$. For this parameter, the zero value of the 

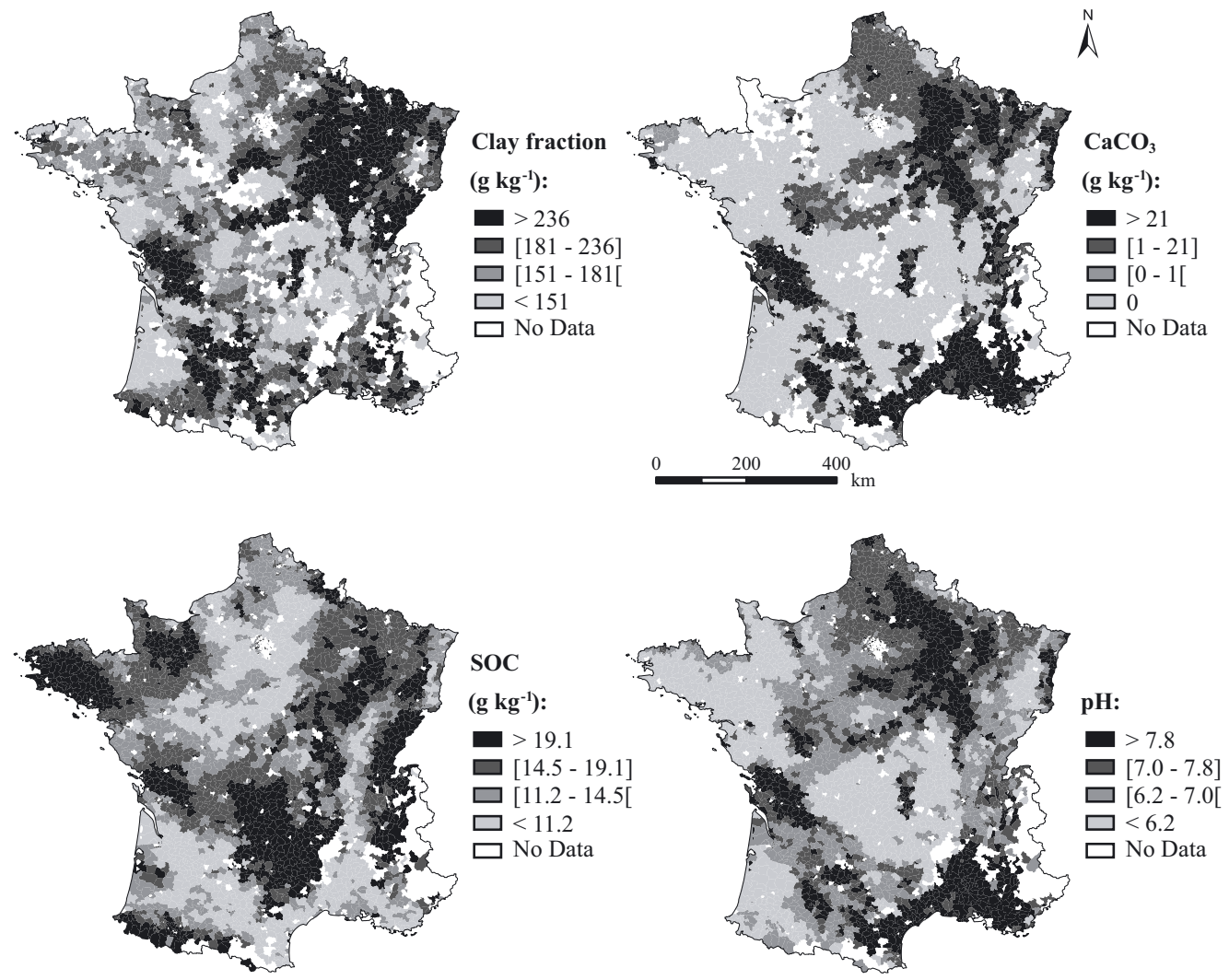

Figure 4. Representation of the reference values for $\mathrm{pH}, \mathrm{CaCO}_{3}$ content, clay fraction and soil organic carbon (SOC), calculated on the cantonal level. (Class thresholds were determined according to non-parametric statistics: 1st quartile - median - 3rd quartile, as calculated on median values for the whole nation.)

first quartile is due to a high proportion of non-calcareous soils on the national scale. This pedological context would explain the lack of information in some areas, as observed in Normandy, where the $\mathrm{CaCO}_{3}$ soil analysis is not systematically performed because of the acidic soil context. As expected, the highest $\mathrm{pH}$ values (> 7.8) are only observed for the canton with the highest $\mathrm{CaCO}_{3}$ median values, and vice versa.

The spatial distribution of the highest clay contents (> $236 \mathrm{~g} \mathrm{~kg}^{-1}$ ) is similar to that of the highest $\mathrm{CaCO}_{3}$ contents $\left(>21 \mathrm{~g} \mathrm{~kg}^{-1}\right)$, except for those cantons located on the Mediterranean coast, which generally show a median clay content value of less than $236 \mathrm{~g} \mathrm{~kg}^{-1}$. The lowest clay values are primarily observed in northern France, the Centre Region and the Aquitaine Basin. Median soil organic carbon (SOC) values reveal a contrasted distribution: the lowest values are essentially observed in basins, plains and the Rhone River valley, while the highest values are located in mountainous or crystalline areas and other regions with sizable animal production activities.

The results in terms of $\mathrm{P}_{2} \mathrm{O}_{5}$ content (Fig. 3) indicate the difficulty involved in using data from a national database to assess soil fertility levels at the national level. The available $\mathrm{P}_{2} \mathrm{O}_{5}$ contents are essentially determined, for each of the various analytical methods, on the basis of soil characteristics and individual laboratory strategies: the Dyer method is used within acidic soil contexts, the Olsen method is less prevalent due to its more recent introduction in France. This dis- parity makes it difficult to aggregate results, given the lack of correlation across these three methods. Moreover, extractable phosphorus contents obtained according to the same methods can lead to different agronomic interpretations with respect to the applicable pedological context and crop production. Extractable $\mathrm{P}$ is not in fact systematically linked to potential crop yield.

Studies undertaken on small spatial scales typically analyze soil nutrient contents quantitatively, by means of numerical and statistical analyses (Fixen, 2006). Such an approach is not consistent on the national scale due to the diversity in analytical methods, which prove difficult to aggregate and which do not account for objectives tied to crop production and diversity in soil type.

\subsection{Agronomic assessment of soil available phosphorus content}

\subsubsection{Effect of reference values on agronomic diagnostic class}

In the case of missing ancillary data, the soil phosphorus bioavailability class was determined by using "reference values". To estimate the effect of these values on soil phosphorus diagnosis on the national scale, a comparison was carried out on 198, 982 samples, all containing ancillary data. The 
Table II. Soil phosphorus bioavailability class frequency $F C_{x}\left(F C_{1}\right.$, $F C_{2}$ and $F C_{3}$ ) determined on 198, 982 soil analyses by taking into account either ancillary data (real values) or reference values and then performing the calculation in equation (2).

\begin{tabular}{lccc}
\hline & $F C_{1}$ & $F C_{2}$ & $F C_{3}$ \\
\hline Real values & 0.45 & 0.29 & 0.26 \\
Reference values & 0.42 & 0.30 & 0.28 \\
\hline
\end{tabular}

bioavailability class was first determined using the actual ancillary data and then just the reference values. Table II presents the bioavailability class frequencies obtained for each of these two procedures.

The results obtained using real values in the diagnostic procedure show a predominant proportion of the $C_{1}$ class $(0.45)$ and a similar proportion of both the $C_{2}$ and $C_{3}$ classes, representing 0.29 and 0.26 , respectively. These frequencies are not significantly different from those obtained with reference values, according to the Wilcoxon test $(P<0.05)$ : introducing reference values does not induce significant differences in the diagnosis. This result serves to justify the possibility of collating all results in order to generate a more comprehensive national overview of the available $\mathrm{P}$ assessment, using reference values to fill in for missing data.

\subsubsection{Interpretations using reference values}

As part of this processing procedure, phosphorus bioavailability classes were determined for all available analyses. In the event of missing ancillary data, we used the reference values for estimation purposes. By implementing this procedure (Fig. 5), it was possible to assign a diagnosis for some cantons that had previously been placed in the "no data" category (Fig. 5). The $C_{1}$ bioavailability class is well represented with a high proportion of cantons $(57 \%)$ featuring a dominant $F C_{1}\left(F C_{1}>F C_{2}\right.$ and $\left.F C_{3}\right)$. The lowest $C_{1}$ frequencies $\left(F C_{1}<0.25\right)$ are mainly located in the northern half of France, essentially in Brittany, Normandy, and the North and Champagne Regions, whereas the highest frequencies $(>0.75)$ are more scattered throughout the rest of France. Conversely, those areas previously characterized by low $F C_{1}$ frequencies exhibit high $F C_{2}$ and $F C_{3}$ values, and areas with a high bioavailability level are often bounded by areas with a dominant $C_{2}$ value.

A significant proportion of French cantons can be categorized in the $C_{1}$ class, which means that the quantity of extractable phosphorus in soils is less than $\mathrm{L}_{1}$, as defined for plants with a low sensitivity to phosphorus availability. In terms of farming practices, this means that the available phosphorus content in soils is considered to be insufficient as regards crop requirements: a complementary fertilization is thus needed to insure an optimal level of productivity for every crop. From an environmental standpoint, this situation might be considered as the lowest pollution risk. In employing the same approach, $18 \%$ of the cantons have a dominant $\mathrm{C}_{3}$ bioavailability; these cantons are characterized by an available phosphorus content higher than the $\mathrm{L}_{2}$ threshold. In this case, the available phosphorus content in soils is considered to be sufficient for all crop production, including those highly sensitive to phosphorus availability without any fertilization; moreover, this practice may be continued for several years. In this case, due to the high amounts of phosphorus accumulated in the soils, transfers to water systems are possible if erosion were to occur. The $C_{2}$ class corresponds to an intermediate situation for which no fertilization is possible for the least demanding crops, but still necessary for crops with high sensitivity to phosphorus availability. In this second case, for the majority of cropping systems, maintaining fertilization (i.e. in compensating for the amounts exported by yields), with priority given to the most demanding crops, is sufficient to maintain the soil available phosphorus content relative to both crop type and yield objectives.

The phosphorus bioavailability class frequencies (Fig. 5) allowed us to map gradients on the national scale from areas categorized in the $C_{1}$ class to those in the $C_{3}$ class. These gradients may be induced by the reference values themselves, whose spatial distribution is structured on the national scale (Saby et al., 2004). Yet, the resulting map reflects land use patterns on the national scale: cattle-breeding areas (Brittany, Normandy, Alsace and northern France) are mainly characterized by the $C_{3}$ bioavailability class, whereas crop-growing areas are characterized by lower bioavailability classes. These observations are in agreement with the conclusions drawn by Withers et al. (2001), who observed that the largest P surpluses in the UK occurred in areas characterized by limited arable soils receiving manure from intensive breeding units, while those farms without manure inputs generated smaller surpluses.

Some biases may serve to skew the final agronomic assessment on the cantonal scale. One such bias involves the calculation of reference values over a 15 -year period on the cantonal scale, which induces a smoothing effect, hence making it impossible to detect fine spatial and temporal variations. Another bias relates to the uncontrolled sampling strategy, which can potentially lead to a statistical bias difficult to assess, such as heterogeneity in the spatial distribution of analyses or variability in farmers' motivations to perform soil analyses, even though these biases are partially offset by the large number of analyses. Considerable care is needed, however, when interpreting the results from this soil analysis database.

\section{CONCLUSION}

This study constitutes the first attempt to assess the agronomic status of French arable topsoil on the national scale, through implementation of the "sustainable fertilization" concept and by incorporating the local specificity of soils and nutrient demand of the future crop. Another originality of this method pertains to the interpretation of quantitative results from the French Soil Test Database (BDAT) and their evaluation using the RegiFert ${ }^{\circledR}$ software. The results show that $77 \%$ of cantons fall under the critical level, according to demanding crop needs. Nevertheless, $23 \%$ still present a soil phosphorus accumulation that remains unnecessary with 

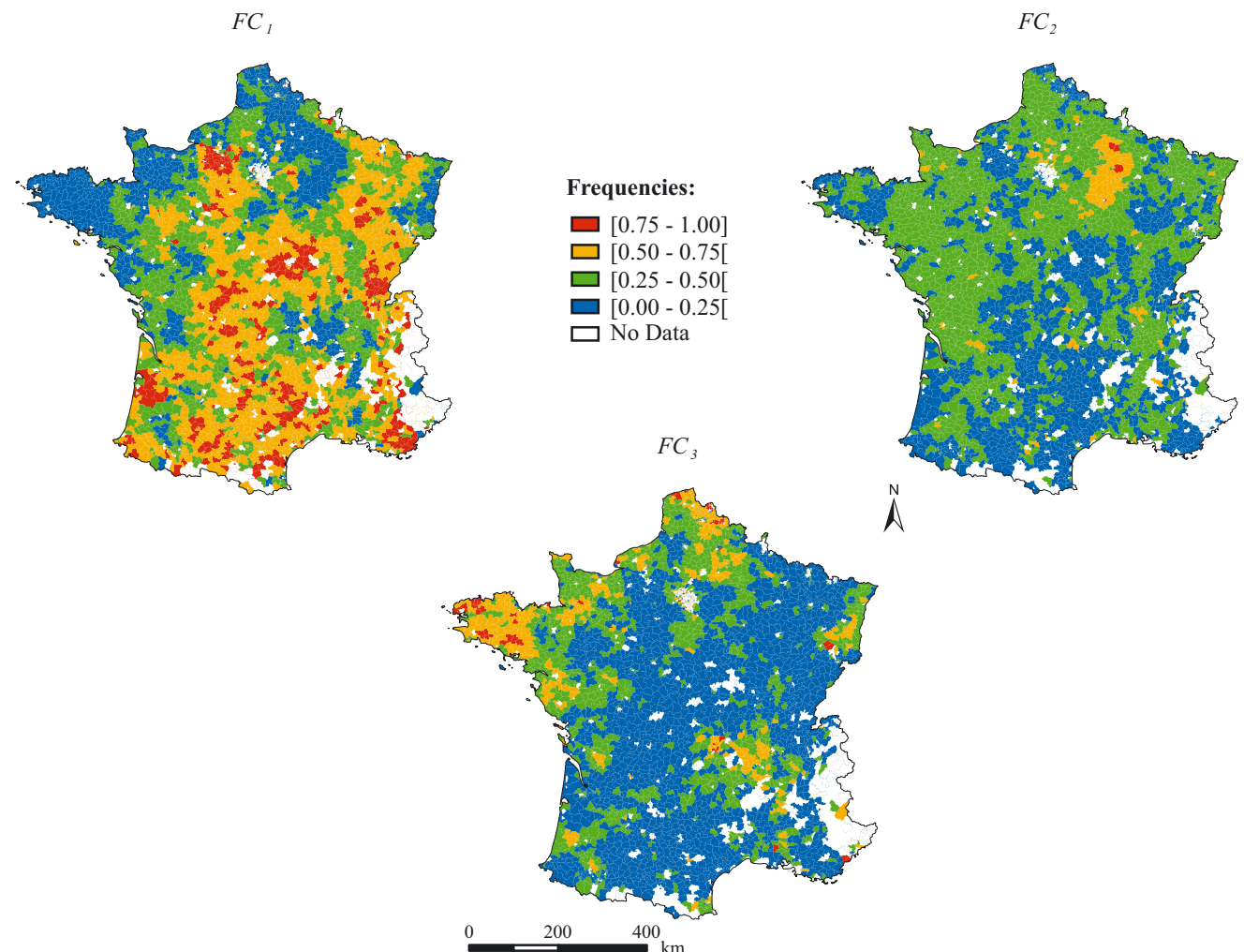

Figure 5. Representation of the phosphorus bioavailability class frequencies $\left(F C_{1}, F C_{2}\right.$ and $\left.F C_{3}\right)$, as calculated on the cantonal scale with the reference value requirement. $\left(C_{1}\right.$ : low level, the extractable phosphorus content is less than the $\mathrm{L}_{1}$ threshold value; $C_{2}$ : intermediate level, the extractable phosphorus content is bounded between the $\mathrm{L}_{1}$ and $\mathrm{L}_{2}$ values; $C_{3}$ : high level, the extractable phosphorus content is greater than the $\mathrm{L}_{2}$ value.)

respect to agricultural uses. According to the associated diagnosis, the main portion of the available phosphorus content in French arable topsoil is considered insufficient, relative to any type of potential crop requirement. From an environmental standpoint, however, this situation could be considered as the lowest pollution risk. On the national scale, bioavailability class frequencies are structured spatially; moreover, gradients are correlated with soil parameter configurations and reflective of land use patterns. Some biases may skew the final agronomic assessment on the cantonal scale. For this reason, further developments are needed in order to fully utilize the possibilities offered by the RegiFert ${ }^{\circledR}$ software in terms of regional parameterization as well as to refine knowledge of local conditions. Nevertheless, these initial results reveal clear spatial trends in the phosphorus bioavailability class distribution. Mapping these trends can be helpful for the national assessment of environmental pressures linked to $\mathrm{P}$ excess in soils and for a better adaptation of policy to regional soil and land use contexts.

\section{REFERENCES}

AFNOR (1996) Qualité des sols, $3^{e}$ éd., Recueil des normes françaises 1996, AFNOR, Paris, 533 p.

Aulakh M.S., Pasricha N.S., Baddesa H.S., Bahl G.S. (1991) Long-term effects of rate and frequency of applied P on crops yields, plant available $\mathrm{P}$, and recovery of fertilizer $\mathrm{P}$ in a peanut-wheat rotation, Soil Sci. 151, 317-332.

COMIFER (1993) Aide au diagnostic et à la prescription de la fertilisation phosphate et potassique des grandes cultures, in: COMIFER (Ed.), $28 \mathrm{p}$.

Cope J.T. Jr. (1981) Effects of 50 years of fertilization with phosphorus and potassium on soil test levels and yields at six locations, Soil Sci. Soc. Am. J. 45, 342-347.

Denoroy P., Dubrulle P., Villette C., Colomb B., Fayet G., Schoeser M., Marin-Laflèche A., Pellerin F., Pellerin S., Boiffin J. (2004) RegiFert - Interpréter les résultats des analyses de terre, in: INRA Techniques et pratiques (Ed.), $129 \mathrm{p}$.

Edwards A.C., Withers P.J.A. (1998) Soil phosphorus management and water quality: a UK perspective, Soil Use Manage. 14, 124-130.

Fixen P.E. (2006) Soil test levels in North America, Better Crops 90, 4-7.

Gachon L. (1988) Phosphore et potassium dans les relations sol-plante. Conséquences sur la fertilisation, in: INRA (Ed.), INRA Paris, $566 \mathrm{p}$.

ITCF (1988) Special Fertilisation phosphore et potasse, in: Perspectives agricoles 277, $266 \mathrm{p}$.

Kamprath E.J. (1967) Residual effect of large applications of phosphorus on high phosphorus fixing soils, Agron. J. 59, 25-27.

Lemercier B., Gaudin L., Walter C., Aurousseau P., Arrouays D., Schvartz C., Saby N.P.A., Follain S., Abrassart J. (2008) Soil phosphorus monitoring at the regional level by means of a soil test database, Soil Use Manage. 24, 131-138. 
Lemercier B., Walter C., Schvartz C., Saby N., Follain S., Arrouays D. (2006) Broad-scale soil monitoring through a nationwide soil-testing database in: Global Workshop on Digital Soil Mapping, Rio, Brasil, July 4-7, 2006.

Lettens S., Van Orshoven J., Van Wesemael B., Muy B. (2004) Soil organic and inorganic carbon contents of landscape units in Belgium derived using data from 1950 to 1970, Soil Use Manage. 29, 40-47.

Morel R., Lasnier T., Bourgeois S. (1984) Les essais de fertilisation de longue durée de la station agronomique de Grignon, in: INRA (Ed.), INRA Paris, $335 \mathrm{p}$.

Pellerin F., Pellerin S., Vilette C., Boiffin J. (2000) Évolution du raisonnement de la fertilisation phosphatée des grandes cultures. Étude par simulation des préconisations de fumure sur un échantillon test représentatif des sols et des successions de culture du nord du Bassin parisien, Étude et Gestion des Sols 7, 53-71.

Rémy J.C., Marin-Laflèche A. (1974) L'analyse de terre : réalisation d'un programme d'interprétation automatique, Ann. Agron. INRA 25, $607-632$.

Saby N., Schvartz C., Walter C., Arrouays D., Lemercier B., Roland N., Squividant H. (2004) Base de données des analyses de terre : procédure de collecte et résultats de la campagne 1995-2000, Étude et Gestion des Sols 11, 235-254.

Schavrtz C., Muller J.C., Decroux J. (2005) Guide de la fertilisation raisonnée, in: La France Agricole (Ed.), 414 p.

Schvartz C., Walter C., Claudot B., Bouédo T., Aurousseau P. (1997) Synthèse nationale des analyses de terre réalisées entre 1990 et
1994. 1. Constitution d'une banque de données cantonale, Étude et Gestion des Sols 4, 191-204.

Sharpley A.N., Foy B., Withers P.J.A. (2000) Practical and innovative measures for the control of agricultural phosphorus losses to water, $\mathrm{CAB}$ international, Wallingford.

Skinner R.J., Todd A.D. (1998) Twenty-five years of monitoring $\mathrm{pH}$ and nutrient status of soils in England and Wales, Soil Use manage. 14, $162-169$.

Stockdale E.A., Shepherd M.A., Fortune S., Cuttle S.P. (2002) Soil fertility in organic farming systems - fundamentally different? Soil Use Manage. 18, 301-308.

Thévenet G. (1993) La fertilisation raisonnée. Du concept du raisonnement aux applications pratiques ; la démarche du COMIFER, Ingénieurs de la vie 427, 28-35.

Walter C., Schvartz C., Claudot B., Aurousseau P., Bouedo T. (1997) Synthèse nationale des analyses de terre : période 1990-1994, $2^{\mathrm{e}}$ éd. augmentée, in: AFES (Ed.), 66 p. and 25 maps.

Withers P.J.A., Edwards A.C., Foy R.H. (2001) Phosphorus cycling in UK agriculture and implications for phosphorus loss from soil, Soil Use Manage. 17, 139-149.

Wivstad M., Dahlin A.S., Grant C. (2005) Perspectives on nutrient management in arable farming systems, Soil Use Manage. 21, 113-121.

Zhang C., McGrath D. (2004) Geostatistical and Gis analyses on soil organic carbon concentration in grassland of south eastern Ireland from two different periods, Geoderma 119, 261-275. 